\title{
PENGEMBANGAN ASSESSMENT FOR LEARNING (AFL) MELALUI LESSON STUDY PADA PRAKTIK PEMESINAN SMK SESUAI KURIKULUM 2013
}

\author{
Endri Triwiyono ${ }^{1}$ \\ 1Jurusan Pendidikan Teknik Mesin FT UNY \\ endri.c215@gmail.com
}

\begin{abstract}
The aim of this research is to: (1) develop an assessment for learning (AFL), and (2) verify the effectiveness of the AFL through lesson study approach on machining practice in SMK. The reseach was a research and development with Borg \& Gall's modified R\&D model which comprised of 3 phase: development, small scale test, and large scale test. The research subjects were the students and teachers of machining program at SMK 2 Depok Sleman. Data were collected through interviews, documentation, questionnaire, notes, observation sheet, assessment sheet and students' response. The descriptive analysis technique was used to analyze the data using rating methods. Results of the research show: (1) an assessment for learning through lesson study approach was successfully developed which consists of the assessment process and the product. Results of the assessment informs about students' processes in practice learning, product quality and overall practice results to determine students' achievement and also serves as formative feedback; (2) the effectiveness of the assessment, which was reviewed for eligibility, was categorized as "very good", whereas from the realibility it was in "good" category. The effectiveness was rated "very good" for its reliability. The implementation was in "good" category with $76.58 \%$ implementation and students' response were good.
\end{abstract}

Keywords: assessment for learning, lesson study, machining practice

\begin{abstract}
ABSTRAK
Penelitian ini bertujuan untuk: (1) pengembangan perangkat assessment for learning, (2) menguji keefektifan perangkat assessmen for learning melalui pendekatan lesson study pada pembelajaran praktik pemesinan. Penelitian pengembangan ini menggunakan modifikasi model Borg \& Gall yang terbagi menjadi 3 tahap yaitu: pengembangan, tahap ujicoba terbatas, dan tahap ujicoba diperluas. Subjek penelitian adalah siswa dan guru teknik pemesinan SMK Negeri 2 Depok Sleman. Pengumpulan data menggunakan wawancara, dokumentasi, angket kuesioner, catatan lapangan, lembar pengamatan, lembar penilaian produk serta respon siswa. Teknik analisis data menggunakan analisis deskriptif dengan metode rating. Hasil penelitian menunjukkan bahwa: (1) perangkat penilaian assessment for learning melalui pendekatan lesson study berhasil dikembangkan berupa perangkat penilaian proses dan produk. Informasi hasil penilaian yaitu informasi akurat proses kerja siswa, kualitas produk serta hasil keseluruhan penilaian praktik untuk mengetahui capaian belajar siswa dan sebagai formatif feedback; (2) efektifitas perangkat ditinjau dari keberfungsian mempunyai hasil penilaian "sangat baik" dan untuk reliabilitas "baik". Keefektifan perangkat masuk kategori "sangat baik" ditinjau dari hasil penilaian dan reliabilitasnya. Tingkat keterlaksanakan masuk kategori "baik" dengan persentase keterlaksanaan 76,58\% dengan respon baik dari siswa.
\end{abstract}

Kata kunci: perangkat assessment for learning, lesson study, praktik pemesinan

\section{PENDAHULUAN}

Era globalisasi berkembang sangat cepat. Berdampak terhadap perkembangan teknologi informasi, tranformasi ekonomi berbasis pengetahuan, perkembangan sosial, dan kompetisi internasional. Menghadapi tantangan tersebut, sistem pendidikan harus direformasi guna menjawab tuntutan yang ada.
Salah satu upaya yang dilakukan yaitu melalui pengembangan kurikulum (Cheng, 2005: 45). Kurikulum merupakan rencana atau program menyangkut semua pengalaman yang dihayati peserta didik dibawah pengarahan sekolah (Oliva, 1982: 2). Pengembangan kurikulum di Indonesia saat ini adalah Kurikulum 2013 yang diterapkan di seluruh jenjang pendidikan (Permendikbud No 60 Th 2014). Implementasi 
Kurikulum 2013 mempunyai beberapa perubahan, salah satunya dalam sistem penilaian hasil belajar. Penilaian ditekankan pada hasil dan proses pembelajaran siswa (Abdullah, 2013: 12).

Penilaian hasil belajar berfungsi memantau proses, kemajuan belajar, dan perbaikan hasil belajar secara berkesinambungan untuk mengetahui capaian pembelajaran (learning outcomes) peserta didik yang diwujudkan dalam penilaian formatif dan sumatif (Permendikbud No 104 Tahun 2014). Penerapan penilaian dilakukan melalui penilaian autentik sebagai bentuk reformasi pendidikan pada level operasional yaitu penilaian (Rojewski, 2009: 31). Reformasi ini bukan hanya sebagai penunjang kesuksesan pelaksanaan Kurikulum 2013, akan tetapi untuk menghadapi tantangan global yang ada. Paradigma reformasi pendidikan yang menitik beratkan pada student center learning menuntut adanya selfassessment dalam proses penilaian sebagai bentuk pembelajaran individual (Cheng, 2005: 5).

Fakta dilapangan menunjukan guru mengalami kesulitan dalam penilaian hasil belajar terutama penilaian formatif/proses sehingga pelaksanaannya belum optimal. Faktor penghambat pelaksanaan penilaiaan formatif yaitu metode, pemanfaatan hasil dan siswa(http://www.suaramerdeka.com/v1/index. php/read/cetak/2014/08/2717; Mansyur, 2009: 35). Hasil prasurvey di SMK pilot project Kurikulum 2013 di Yogyakarta yaitu SMK N 2 Depok Sleman dan SMK N 2 Pengasih Kulonprogo khususnya teknik pemesinan menunjukan belum adanya implementasi penuh terhadap penilaian Kurikulum 2013. Kegiatan praktik produktif yang dilaksanakan sudah menempatkan proporsi terhadap penilaian proses dan hasil produk. Akan tetapi, terdapat beberapa permasalahan terkait pelaksanaan penilaian proses/ formatif ini. Permasalahan tersebut adalah pada perangkat dan cara penilaian formatif siswa dengan jumlah yang lebih banyak serta lebih aktif dan dinamis. Oleh karena itu, solusi pemecahan permasalahan di atas yaitu dengan mengembangkan perangkat penilaian guna mengakomodasi penilaian praktik pemesinan tersebut.

Assessment for learning merupakan sebuah kekuatan baru dari penilaian formatif yang dinilai belum berjalan secara optimal. Assessment for learning dapat dikembangkan sebagai solusi untuk menilai proses belajar siswa khususnya praktik produktif pemesinan meskipun penilaian hasil tetap dilaksanakan. Penerapan assessment for learning ini secara langsung menjadi upaya implementasi self assessment sebagai bentuk reformasi penilaian dalam pendidikan kejuruan saat ini. Hal ini karena self assessment merupakan salah satu prinsip dasar pelaksanaan assessment for learning (ARG, 2002: 1; Clarke, 2005: 5; Jones, 2005: 7; QIA, 2008: 3; Briggs, 2009: 7; Heritage, 2010: 10).

Penerapan assessment for learning dilapangan tidak ada perbedaan terhadap penerapan penilaian formatif (ARG, 2002: 1; Boston \& Carol, 2002: 1; QIA, 2008: 2; Mansyur, 2009: 21; Stiggins \& Chappuis, 2012: 12). Kesulitan guru dikarenakan perbandingan siswa yang lebih besar, sehingga guru hanya melakukan pengamatan sesaat. Upaya yang dapat dilakukan yaitu mengimplementasikan assessment for learning melalui kegiatan kolaboratif guru dalam melakukan penilaian proses. Pada dasarnya assessment for learning merupakan bentuk penilaian belajar siswa yang implementasinya dapat diintegrasikan dengan pendekatan lain sehingga penerapan kombinasi assessment for learning dapat dilaksanakan selama prinsip dasar mendukung satu sama lain (Widihastuti, 2014: 281).

Lesson study dapat dikombinasikan sebagai upaya pendekatan penilaian. Lesson study merupakan sebuah pendekatan pengembangan profesionalitas guru dengan prinsip kolegialitas dan kolaboratif. Dalam praktiknya lesson study terbukti dapat meningkatkan kompetensi guru dalam pembelajaran (Triwaranyu, 2007: 25; Marsigit, 
et al., 2010: 30; Tuerah, 2014: 35). Assessment for learning yang merupakan bagian dari pembelajaran dapat menggunakan lesson study sebagai sintaks penilaian yang dilakukan.

Prinsip dasar assessment for learning dan lesson study mempunyai kesamaan dalam penilaian proses/formatif antara lain: pertama, fokus kegiatan observasi yang dilaksanakan berpusat pada bagaimana siswa belajar/ proses belajar siswa (ARG, 2002: 1; Gardner, 2009: 9-13; Lenski \& Caskey, 2009: 56; Dudley, 2013: 107); kedua, proses refleksi dan feedback menjadi hal yang paling penting dalam setiap kegiatan, sebagai koreksi dan perbaikan pembelajaran (White \& Lim, 2008: 924; Post \& Varos, 2008: 473; Perry \& Lewis, 2009: 372).

Lesson study mendukung assessment for learning yang mengedepankan proses observasi, refleksi dan feedback. Kolaboratif antar guru dapat diiimplementasi dalam assessment for learning dimulai dari rencana, proses observasi mendetail pada aktifitas siswa hingga refleksi temuan hasil (Dotger, et al, 2013: 29 ; Chaona \& Inprasitha, 2013: 1072).

Penerapan assessment for learning melalui pendekatan lesson study secara langsung dapat menjawab tuntutan pedoman pelaksanaan Kurikulum 2013 yaitu Permendikbud No 81A Tahun 2013 Lampiran IV yang secara tidak langsung guru dituntut dapat mengembangkan penilaian secara individu ataupun kelompok.

Berdasarkan hal di atas perlu dilakukan pengembangan perangkat assessment for learning melalui pendekatan lesson study khususnya pada pembelajaran praktik pemesinan sesuai Kurikulum 2013. Diharapkan penilaian praktik produktif dapat menilai secara valid dan reliabel proses dan produk siswa menggunakan perangkat yang dikembangkan.

Terkait dengan hal ini maka permasalahan yang diajukan adalah sebagai berikut: 1) bagaimana pengembangan perangkat assessment for learning melalui lesson study pada pembelajaran praktik pemesinan di SMK; 2) bagaiman keefektifan perangkat assessmen for learning melalui pendekatan lesson study pada penilaian pembelajaran praktik pemesinan di SMK.

Berdasarkan permasalahan yang diajukan diatas maka penelitian ini bertujuan untuk: (1) mengembangkan perangkat assessment for learning melalui pendekatan lesson study pada pembelajaran praktik pemesinan di SMK; (2) menguji keefektifan perangkat assessmen for learning melalui pendekatan lesson study pada pembelajaran praktik pemesinan di SMK.

Produk yang dikembangkan dalam penelitian ini adalah perangkat assessment for learning melalui pendekatan lesson study pada penilaian proses praktik siswa SMK bidang keahlian teknik pemesinan, Spesifikasi produk yang akan dihasilkan dari penelitian ini adalah: (1) sintaks alur proses penilaian menggunakan sintaks lesson study yang terdiri dari alur plando-see-redesign dengan observer sebagai pengamat kegiatan yang dilaksanakan; (2) pedoman penilaian sebagai acuan kegiatan assessment for learning melalui lesson study yang dilaksanakan; (3) perangkat assessment for learning yang terdiri dari penilaian proses (keterampilan dan sikap kerja) dan hasil produk.

\section{METODE}

Penelitian ini merupakan penelitian pengembangan (Research \& Development) Borg \& Gall (1983). Langkah penelitian terbagi menjadi tiga tahap yaitu penyusunan perangkat (need assessment \& validasi pakar), ujicoba terbatas dan ujicoba diperluas. Pelaksanakan ujicoba terbatas dan diperluas dilakukan di dua SMK Teknik Pemesinan yaitu SMK N 2 Depok dan SMK N 2 Pengasih dengan bantuan masing-masing 4 observer guru.

Prosedur pengembangan yaitu prosedur pengembangan Borg \& Gall dengan metode penelitian yang digunakan quasi experimentall 
eksperimen semu. Desain eksperimen yang digunakan adalah the one-shot case study.

Data penelitian terbagi menjadi dua yaitu data kualitatif dan kuantitatif. Data kualitatif merupakan data hasil catatan lapangan, sementara data kuantitatif didapat dari hasil penilaian angket. Instrumen yang digunakan yaitu kuesioner dan catatan lapangan melalui teknik angket dan observasi dalam penilaian keberfungsian, efektifitas dan keterlaksanaan.

Sesuai data yang didapat analisis dilakukan pada data kualitatif dan kuantitatif. Analisis data kualitatif dilakukan dengan metode deskriptif. Analisis data kuantitatif dilakukan melalui metode rating yang selanjutnya dilakukan pengkategorian terhadap hasil penilaian. Reliabilitas antar rater dilakukan dengan menggunakan koefisien korelasi antar kelas (Interclass Corelation Coefficients/(CC).

\section{HASIL DAN PEMBAHASAN}

Perangkat berhasil dikembangkan melalui penelitian pengembangan Borg \& Gall yang selanjutnya sudah valid dan reliabel berdasarkan hasil penilaian para pakar sehingga dinyatakan layak digunakan. Adapun spesifikasinya sebagai berikut: (1) perangkat yang dikembangkan merupakan penilaian pembelajaran praktik pemesinan khususnya membubut kompleks; (2) penerapan mengkombinasikan prinsip assessment for learning dipadukan prinsip lesson study melalui langkah plan, do, see dan redesign dalam setiap langkah melalui kegiatan kolaboratif guru; (3) langkah penilaian terbagi menjadi tiga langkah sebagai berikut: (a) langkah awal yaitu diskusi plan. Plan merupakan perencanaan dan persiapan penilaian yang akan dilaksanakan. Pembahasan pada kriteria dan tujuan penilaian selain juga terkait RPP dan jobsheet. Hasil diskusi selanjutnya disampaikan kepada siswa. (b) langkah kedua fase $d o$. Fase do dilakukan melalui kegiatan pengamatan secara kolaboratif guru terhadap aktifitas belajar siswa serta penilaian produk yang memfasilitasi self assessment siswa. Pengamatan/observasi dipilih sebagai upaya pengambilan data proses belajar karena merupakan sebuah upaya untuk melihat kondisi nyata apa yang dikerjakan siswa dengan menitik beratkan atau fokus pada kegiatan belajar siswa (Moore \& Stanley, 2010: 42; Berry, 2008: 99; Briggs,et al, 2008: 19-21). Hal penting dalam fase do adalah penggunakan nametag untuk setiap siswa serta tabel bantu pengamatan sebagai upaya mempermudah pengamatan observer; (c) langkah ketiga yang dilakukan merupakan fase see. See diterapkan melalui kegiatan diskusi refleksi terkait dengan hasil penilaian proses maupun produk. Refleksi dan respon merupakan tindak lanjut terhadap hasil temuan. Refleksi dilakukan untuk merespon terkait temuan penilaian baik proses kerja maupun produk. Bentuk kolaboratif guru dan siswa dalam fase see yaitu dengan pemberian umpan balik formatif serta diskusi terkait hasil refleksi. Penyampaian hasil refleksi dapat dilakukan guru melalui diskusi secara personal dengan siswa terhadap hasil pengamatan individu serta dapat dilakukan melalui diskusi secara umum terhadap hasil pengamatan kelas secara umum. (Gambar 1. Alur Penilaian AfL melalui Pendekatan Lesson Study); (4) perangkat ini mempunyai dua komponen yaitu: (a) perangkat penilaian proses (keterampilan dan sikap kerja). Perangkat ini digunakan untuk mengamati proses praktik siswa melalui metode kolaboratif beberapa observer; (b) perangkat penilaian produk . Perangkat penilaian produk berisi lembar penilaian produk yang didalamnya terdapat lembar penilaian dimensi ukuran (umum, ISO dan Khusus), kualitas permukaan serta performance sebagai total nilai produk. Selain itu, terdapat kolom hasil pengamatan keterampilan dan sikap sebagai pengurang. Perangkat penilaian produk yang dibuat mengakomodasi self assessment siswa dan juga penilaian guru. Hal penting dalam 
pengisian oleh siswa adalah penilaian produk harus diisi secara bersamaan sehingga terjadi konfirmasi dan interaksi hasil secara langsung oleh guru kepada siswa. (5) Hasil dari rangkaian kegiatan AfL melalui pendekatan lesson study yaitu: (a) hasil penilaian proses, produk dan praktik secara keseluruhan; (b) umpan balik formatif hasil pengamatan proses praktik siswa, sehingga siswa akan mengetahui kelemahan dan kesalahannya. Sementara guru

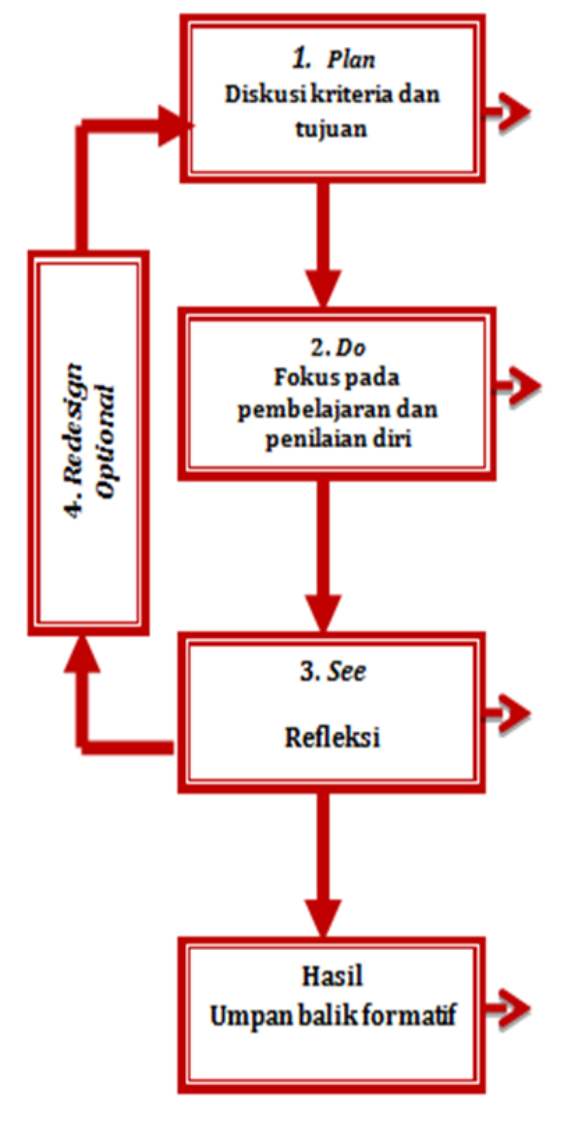

dapat melakukan perbaikan yang tepat sesuai kebutuhan siswa; (c) umpan balik formatif kegiatan pembelajaran secara umum, yaitu berdasarkan hasil pengamatan proses yang dilaksanakan, akan terpetakan kelemahan dan kekurangan kegiatan pembelajaran yang dilaksanakan. Perbaikan pembelajaran dapat dilakukan terkait hasil temuan tersebut untuk meningkatkan kualitas pembelajaran.

\begin{tabular}{|l|l|l|}
\hline \multicolumn{2}{|c|}{ Aktifitas } & \multirow{2}{*}{ Perangkat } \\
\hline $\begin{array}{l}\text { Kolaboratif } \\
\text { antar guru }\end{array}$ & $\begin{array}{c}\text { Kolaboratif } \\
\text { guru dan siswa }\end{array}$ & \\
\hline $\begin{array}{l}\text { Diskusi } \\
\text { kriteria dan } \\
\text { tujuan }\end{array}$ & $\begin{array}{l}\text { Shoptalk dan } \\
\text { demontrasi } \\
\text { pelaksanaan }\end{array}$ & $\begin{array}{l}\text { a.RPP } \\
\text { b.Jobsheet } \\
\text { c.Perangkat } \\
\text { AfL }\end{array}$ \\
\hline
\end{tabular}

\begin{tabular}{|c|c|c|}
\hline $\begin{array}{l}\text { Pengamatan } \\
\text { kolaboratif } \\
\text { proses } \\
\text { praktik }\end{array}$ & $\begin{array}{l}\text { a.Penilaian } \\
\text { produk oleh } \\
\text { siswa dan } \\
\text { guru secara } \\
\text { bersama } \\
\text { b.Diskusi hasil } \\
\text { penilaian } \\
\text { produk }\end{array}$ & \begin{tabular}{|l} 
a. Nametag \\
b.Tabel \\
pengamatan \\
c. Perangkat \\
AfL
\end{tabular} \\
\hline
\end{tabular}

\begin{tabular}{|l|ll|l|}
\hline $\begin{array}{l}\text { Diskusi } \\
\text { refleksi hasil } \\
\text { penilaian } \\
\text { proses dan } \\
\text { produk }\end{array}$ & a. & $\begin{array}{l}\text { Penyampaia } \\
\text { n hasil } \\
\text { refleksi }\end{array}$ & $\begin{array}{l}\text { Hasilpenilaian } \\
\text { proses dan } \\
\text { produk }\end{array}$ \\
& $\begin{array}{l}\text { Diskusi } \\
\text { hasil refleksi }\end{array}$ & \\
\hline
\end{tabular}

$$
\begin{aligned}
& \text { a. Penilaian proses, produk dan praktik } \\
& \text { secara keseluruhan } \\
& \text { b. Umpan balik formatif per siswa } \\
& \text { c. Umpan balik formatif kegiatan } \\
& \text { pembelajaran }
\end{aligned}
$$

Gambar 1. Alur Penilaian AFL melalui Pendekatan Lesson Study

Hasil efektifitas perangkat terbagi menjadi penilaian keberfungsian, efektifitas, keterlaksanaan, respon siswa dan hasil penilaian penerapan perangkat. Adapun hasil tersebut sebagai berikut: (1) hasil penilaian keberfungsian bahwa perangkat penilaian keterampilan, sikap maupun produk dari aspek petunjuk penggunaan, materi serta tata bahasa sangat baik dengan reliabilitas antarpenilai kategori good agreement atau sudah memenuhi syarat reliabel; (2) keefektifan perangkat dilihat dari aspek validitas, reliabilitas, objektifitas, sistematika dan kepraktisan sudah sangat baik. Koefisien reliabilitas antarpenilai sudah termasuk kategori very good agreement dan sudah sesuai dengan syarat reliabel. Sehingga perangkat assessment for learning melalui lesson study dapat dijadikan sebagai perangkat penilaian praktik khususnya pemesinan bubut; (3) keterlaksanaan assessment for learning melalui lesson study disetiap siklus baik fase plan, do, see dan redesign secara umum masuk 
dalam kategori baik dengan tingkat keterlaksanaan $76,58 \%$. Koefisien hasil penilaian antar penilai masuk dalam kategori good agreement sehingga hasil penilaian keterlaksanaan ini sudah sesuai dengan syarat reliabel; (4) siswa secara langsung mengikuti proses penilaian yang dilaksanakan, sehingga respon siswa sangat diperlukan. Respon siswa secara umum sudah baik. Tinjauan respon siswa dari beberapa aspek yaitu prosedur, pengamatan observer, perangkat penilaian dan feedback. Prosedur ditinjau dari kemudahan pedoman dan penggunakan peralatan bantu seperti nametag. Pengamatan observer ditinjau dari pelaksanaannya. Perangkat penilaian produk ditinjau dari petunjuk, bahasa, item, serta kemudahan pengisian. Feedback ditinjau dari proses timbal balik guru. Kesepakatan penilaian siswa diketahui bahwa reliabilitas antar penilai yaitu 0,722 yang tergolong dalam kategori good agreement, sehingga sudah memenuhi syarat reliabel (Hasil analisis pada tabel 1); (5) Hasil penilaian total yang dilakukan bahwa seluruh siswa lulus dengan nilai diatas nilai minimal KKM (Kriteria Ketuntasan Minimal). KKM di SMK N 2 Depok Sleman lebih tinggi dari standar yaitu 76. Selain penilaian produk juga didapat hasil catatan berdasarkan penilaian keterampilan dan sikap kerja, beberapa hal kesalahan praktik pemesinan bubut yang dilakukan siswa secara umum adalah: (a) keterampilan kerja. Kesalahan pada setting kecepatan putar, siswa masih menggunakan kecepatan tinggi meskipun dalam pengerjaan khusus seperti mengulir. Pemberian cairan meskipun coolant pada mesin sudah tidak otomatis, tetapi tidak diberi coolant secara manual. Selain itu, kedalaman pemakanan belum diperhatikan oleh siswa; (b) sikap kerja. Kesalahan praktik yaitu siswa kurang memperhatikan keselamatan dan kesehatan kerja salah satunya adalah penggunakan pelindung mata. Hasil pengamatan nyaris siswa tidak menggunakan meskipun sudah disediakan. Penataan peralatan bantu dan alat ukur sangat tidak rapi dan ditempatkan secara menumpuk diatas mesin.
Banyak siswa yang masih menggunakan tangan ketika membersihkan beram ketika mesin berputar. Pemberian umpan balik formatif terhadap proses praktik siswa dapat menurunkan tingkat kesalahan praktik siswa dengan rerata $11,29 \%$ menjadi $8,39 \%$. Adanya pemberian umpan balik formatif, guru dapat memberikan arahan berdasarkan kebutuhan ataupun kesalahan siswa sehingga praktik selanjutnya dapat lebih baik.

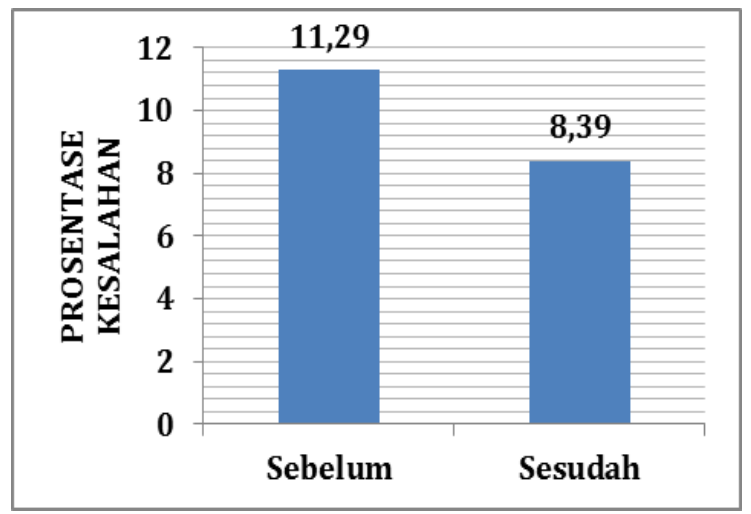

Gambar 2. Prosentase Kesalahan Praktik

Adapun keunggulan dari penggunakan perangkat assessment for learning melalui lesson study ini adalah: (1) perangkat ini mampu menilai praktik siswa dari segi proses kerja (keterampilan dan sikap) dan hasil produk, yang kemudian didapat hasil penilaian total yang valid dari akumulasi keduanya; (2) perangkat ini dapat digunakan sebagai acuan koreksi kegiatan praktik yang dilakukan siswa sehingga dapat diketahui kesulitan selama proses pembuatan job sehingga guru dapat membimbing dan memberi arahan secara tepat. (3) subjektifitas dalam penilaian produk dapat dikurangi dengan indikator penilaian yang jelas serta lembar penilaian yang didesain diisi oleh guru dan siswa; (4) pengamatan secara individual kepada siswa tentu akan membawa dampak positif yaitu terbinanya komunikasi antara guru dan siswa; (5) hasil praktik tidak hanya berupa nilai tetapi juga deskripsi proses praktik yang telah dilakukan siswa sesuai pedoman Kurikulum 2013; (6) penilaian produk yang dirancang sedemikian sehingga siswa mempunyai wadah untuk self assessment dan 
koreksi diri terkait dengan hasil produk; (7) dapat mendukung profesionalitas guru dengan penguatan kolaboratif dan kolegialitas melalui kegiatan lesson study yang dilakukan; (8) kualitas pembelajaran ditingkatkan dan diperbaiki secara terus menerus berdasarkan temuan hasil perpertemuan yang kemudian diproses secara bersama-sama melalui alur plan, do, see dan redesign.

Keterbatasan dari penggunakan perangkat ini adalah: (1) indikator penilaian proses lebih spesifik pada proses pemesinan bubut; (2) untuk hasil penilaian proses yang akurat perlu dilakukan pengamatan secara penuh pada setiap siswa; (3) untuk hasil yang lebih akurat dan siklus lesson study dapat berjalan dengan lancar membutuhkan lebih dari satu guru atau ada observer yang membantu. Sementara jadwal guru sangat padat, sehingga perlu dirancang mengenai jadwal/waktu diskusi, pengamatan dan refleksi.

Tabel 1. Hasil Analisis Penelitian

\begin{tabular}{|c|c|c|c|c|c|c|}
\hline No & Penilaian & Indikator & Validitas & Ket & Reliabilitas & Ket \\
\hline \multirow[t]{4}{*}{1} & Keberfungsian & Keterampilan & 3,79 & Baik sekali & 0,783 & Good \\
\hline & & Sikap & 3,54 & Baik sekali & 0,857 & Very good \\
\hline & & Produk & 3,52 & Baik sekali & 0,763 & Good \\
\hline & Rerata & & 3,63 & Baik sekali & 0,801 & Very good \\
\hline \multirow[t]{6}{*}{2} & Kefektifan & Validitas & 3,88 & Baik sekali & & \\
\hline & & Reliabilitas & 3,33 & Baik sekali & & \\
\hline & & Objektifitas & 3,50 & Baik sekali & 0814 & Verv oood \\
\hline & & Sistematika & 3,08 & Baik & 0,014 & very gooa \\
\hline & & Kepraktisan & 3,67 & Baik sekali & & \\
\hline & Rerata & & 3,52 & Baik sekali & & \\
\hline \multirow[t]{5}{*}{3} & Keterlaksanaan & Plan & 2,63 & Cukup & & \\
\hline & & Do & 3,10 & Baik & & \\
\hline & & See & 2,94 & Baik & 0,742 & Good \\
\hline & & Redesign & 3,38 & Baik sekali & & \\
\hline & Rerata & & 3,06 & Baik & & \\
\hline \multirow[t]{5}{*}{4} & Respon siswa & Prosedur & 3,10 & Baik & & \\
\hline & & Pengamatan & 3,29 & Baik sekali & & \\
\hline & & Perlengkapan & 3,26 & Baik sekali & 0,722 & Good \\
\hline & & Feedback & 3,26 & Baik sekali & & \\
\hline & Rerata & & 3,23 & Baik & & \\
\hline
\end{tabular}

\section{SIMPULAN}

Simpulan hasil penelitian yaitu: (1) perangkat terdiri dari tiga perangkat utama yaitu penilaian keterampilan kerja, sikap kerja dan produk. Metode yang digunakan adalah pengamatan kolaboratif serta penilaian produk yang memfasilitasi siswa dalam self assessment. Informasi hasil penilaian yang diperoleh yaitu informasi akurat proses kerja (keterampilan dan sikap kerja), kualitas produk serta hasil dari praktik secara keseluruhan. Bentuk pemanfaatan sebagai hasil penilaian kompetensi siswa, feedback formatif serta bahan perbaikan pembelajaran; keberfungsian perangkat dilihat dari panduan penggunakan, cakupan materi serta bahasa untuk validitas sudah "sangat baik" sementara reliabilitas dalam kategori "good agreement" atau memenuhi syarat reliabel. Tingkat keterlaksanaan dalam kategori "baik" dengan tingkat keterlaksanaan 76,58\%. (3) keefektifan perangkat dilihat dari aspek validitas, reliabilitas, objektifitas, sistematika dan kepraktisan, termasuk dalam kategori "sangat baik", sementara reliabilitas termasuk kategori very good agreement dan memenuhi syarat reliabel. (4) respon siswa termasuk kategori "baik" dalam mengikuti penilaian ditinjau dari prosedur penilaian, proses pengamatan yang dilakukan observer, penggunakan perangkat penilaian serta feedback yang diberikan guru. 


\section{DAFTAR RUJUKAN}

Abdulah, L.H. 2013. Sistem penilaian dalam Kurikulum 2013: Kajian Dokumen Terhadap Kurikulum 2013. Diakses pada 8 Oktober 2015, https:// www.academia.edu / 5253890 / Sistem_Penilaian__dalam_K urikulum_2013_Kajian_Dokumen.

Berry, R. 2008. Assessment for learning. Aberdeen: Hongkong University Press.

Borg, W.R. \& Gall, M.D. 1983. Educational research: An introduction (4th ed.). New York: Longman.

Boston \& Carol. 2002. The concept of formative assessment. Journal of Practical Assessment, Reseach \& Evaluation, 8(9). In Widihastuti. (2014). Model pengembangan assesment for learning (AfL) berbasis higher order thinking skills (HOTS) untuk pembelajaran bidang busana bagi mahasiswa calon guru pendidikan vokasi. Jurnal Penelitian dan Evaluasi Pendidikan Tahun 18 No 2, 2014 hal 275-289, Universitas Negeri Yogyakarta, Yogyakarta.

Briggs, M., Woodfield, A., Martin, C. 2008. Assessment for learning and teaching. Glasgow: Bell \& Bin Ltd.

Chaona, S. \& Inprasitha, N. 2013. Teacher's assessment for students' learning in classroom using lesson study and open approach. Psychology 2013 Scires Vol 4, No 12, pp 1069-1072.

Cheng, Y.C. 2005. New paradigm for reengineering education, globalization, localization and individualization. Netherland: Springer

Clarke, S. 2005. Formative assessment in action: Weaving the elements together. London: Great Britain for Hodder Murray.

Dotger, S., Maquin, F.K., \& Hammond, K. 2013. Using lesson study to assess student thinking in science. Educator's Voice Volume V, pp 22-31.

Dudley, P. 2013. Teacher learning in lesson study: What interaction-level discourse analysis revealed about how teachers utilised imagination, tacit knowledge of teaching and fresh evidence of pupils learning, to develop practice knowledge and so enhance their pupils' learning.
Teaching and Teacher Education 34 (2013) pp 107-121.

Gardner, J. 2009. Assesment for learning: A practical guide. Belfast: A CCEA Publication.

Heritage, M. 2010. Formative assessment: Making it happen in the classroom. California: Corwin.

Jones, C. A. 2005. Assessment for learning. Vocational Learning Support Programme: 16-19. London: Learning and Skills Development Agency, www.LSDA.org.uk.

Lenski, S.J. \& Caskey, M.M. 2009. Using the lesson study approach to plan of student learning. Middle School Journal, Vol. 40, No. 3 (Januari 2009), pp. 50-57.

Mansyur. 2009. Pengembangan model assessment for learning pada pembelajaran matematika di SMP. (Disertasi doctor, Universitas Negeri Yogyakarta, 2009). Jurnal Penelitian dan Evaluasi Pendidikan, Tahun 15 No 1, 2011 hal 71-91, Universitas Negeri Yogyakarta, Yogyakarta. Diambil dari http://journal.uny.ac.id/index.php/jpep/a rticle/view/1088/1140

Marsigit, Hartono, Sahid, Aryadi. 2010. Pengembangan kompetensi guru matematika SMP RSBI melalui lesson study. Fakultas Matematika dan Ilmu Pengetahuan Alam, Universitas Negeri Yogyakarta, Yogyakarta.

Menteri Pendidikan dan Kebudayaan. 2014. Peraturan Menteri Pendidikan dan Kebudayaan No 60 Tahun 2014 tentang Implementasi Kurikulum di Sekolah Menengah Kejuruan.

Menteri Pendidikan dan Kebudayaan. 2014. Peraturan Menteri Pendidikan dan Kebudayaan No 81 Tahun 2014 tentang Implementasi Kurikulum 2013.

Menteri Pendidikan dan Kebudayaan. 2014. Peraturan Menteri Pendidikan dan Kebudayaan No 104 tahun 2014 tentang Penilaian Hasil Belajar oleh Pendidik pada Pendidikan Dasar dan Pendidikan Menengah.

Moore, B. \& Stanley, T. 2010. Critical thinking and formative assessment. New York: Eye on Education Inc.

Oliva Peter F. 1982. Developing the curriculum. New York: Harper Collins Publisher. 
Perry, R.R. \& Lewis, C.C. 2009. What is successful adaptation of lesson study in US?. J Educ Change (2009) Springer Science+Business Media B.V 10. pp 365-391.

Post, G. \& Varos, S. 2008. Lesson study groups with prospective and practicing teachers. Teaching Childern Mathematics, Vol 14, No 8 (April 2008), pp. 472-478.

Rojewski. J.W. 2009. A conceptual framework for technical and vocational education and training. In Mclean, R. \& Wilson, D. (Eds.). International handbook of education for the changing world of work. Montreal: Springer.

Stiggin, R.J. \& Chappuis, J. 2012. An introduction to student-involved assessment for learning. Six Edition. Pearson Assessment Training Institute. Boston: Pearson Education, Inc.

Triwaranyu, C. 2007. Models and strategies for initial implementation of lesson study in schools. ProQuest Midlle School Journals Vol. 3 No. 3 Winter
2007. Chulalongkorn University, Thailand.

Tuerah P.E.A. 2014. Dampak lesson study terhadap mata pelajaran matematika SMP Sulawesi Utara. Jurnal Penelitian dan Evaluasi Pendidikan Tahun 18 No 2, 2014 hal 234- 245, Universitas Negeri Yogyakarta, Yogyakarta. Diambil dari http://journal.uny.ac.id/index.php/jpep/a rticle/view/2863/2390

White, S.L. \& Lim,C.S. 2008. Lesson study in Asia Pacific classrooms: Local responses to a global movement. ZDM Mathematic Education (2008) 40: pp 915-925.

Widihastuti. 2014. Model pengembangan assesment for learning (AfL) berbasis higher order thinking skills (HOTS) untuk pembelajaran bidang busana bagi mahasiswa calon guru pendidikan vokasi. Jurnal Penelitian dan Evaluasi Pendidikan Tahun 18 No 2, 2014 hal 275-289, Universitas Negeri Yogyakarta, Yogyakarta. Diambil dari http://journal.uny.ac.id/index.php/jpep/a rticle/view/2866/2393 